\title{
Renata Stachura-Lupa*
}

\section{Detektyw Fryga na tropie Henryk Nagiel Tajemnica Nalewek i Sęp}

Henryk Nagiel był z pewnością postacią nietuzinkową, choć czas okazał się dla jego spuścizny literackiej i publicystycznej niełaskawy. Powieści Nagiela nie zagościły w podręcznikach historii literatury i nie zaprzątały uwagi badaczy, jeśli nie liczyć wzmianek w pracach poświęconych rozwojowi powieści tajemnic w Polsce (artykuł Józefa Bachórza w Formach literatury popularnej i hasło w Słowniku literatury popularnej'), obrazowi Warszawy w literaturze polskiej XIX wieku² czy dziejom prasy polonijnej (historycy prasy polskiej znają Nagiela jako dziennikarza i działacza polonijnego w USA, autora m.in. monografii Dziennikarstwo polskie w Ameryce i jego 30-letnie dzieje ${ }^{3}$ ). Jakiegoś wzrostu zainteresowania życiem i twórczością pisarza - zarówno wśród badaczy, jak i czytelników - można spodziewać się w związku ze wznowieniem przez Wydawnictwo CM w ramach serii Kryminały Przedwojennej Warszawy dwóch jego powieści: Tajemnic Nalewek (2013) i Sepa (2014). Z lat ostatnich wymienić warto artykuły Marii Jolanty

* Dr hab. prof. UP; Uniwersytet Pedagogiczny im. KEN w Krakowie, Katedra Literatury Polskiej XIX wieku, Katedra Literatury Współczesnej i Krytyki Literackiej; ul. Podchorążych 2, 30-084 Kraków; e-mail: renata.stachura-lupa@up.krakow.pl.

1 Zob. J. Bachórz, Polska powieść tajemnic w pierwszym ćwierćwieczu jej istnienia, w: Formy literatury popularnej, pod red. A. Okopień-Sławińskiej, Zakład Narodowy im. Ossolińskich, Wydawnictwo PAN, Wrocław-Warszawa 1973, s. 115-135 i tenże, Powieść tajemnic, w: Słownik literatury popularnej, pod red. T. Żabskiego, Wydawnictwo Uniwersytetu Wrocławskiego, Wrocław 2006, s. 485-488.

2 Zob. J. Detko, Warszawa naturalistów, Państwowy Instytut Wydawniczy, Warszawa 1980, s. 88-93; E. Sawicka, Henryk Nagiel i tajemnice Nalewek, w: Warszawa pozytywistów, pod red. J. Kulczyckiej-Saloni i E. Ihnatowicz, Wydawnictwo Instytutu Badań Literackich PAN, Warszawa 1992, s. 101-102. Twórczości Nagiela nie odnotowuje Bibliografia literatury polskiej "Nowy Korbut".

3 Zob. A. Paczkowski, Prasa polonijna w latach 1870-1939. Zarys problematyki, Biblioteka Narodowa, Warszawa 1977. 
Olszewskiej i Ewy Ihnatowicz ${ }^{4}$, podejmujące temat miasta w Tajemnicach Nalewek. Szczególnie interesująco, nie tylko na tle dotychczasowych badań nad twórczością Nagiela, ale i nad twórczością kryminalną XIX wieku w ogóle, wypadają ustalenia Ihnatowicz wskazujące na związki powieści z „narracyjną konwencją przewodnika miejskiego, wspomaganą przez konwencję dziennikarsko-reporterskiego doniesienia w kolumnie miejskiej" 5 .

Obie powieści Nagiela doczekały się wznowień jeszcze na przełomie XIX i XX wieku, co świadczy o ich niegdysiejszej popularności: Tajemnice Nalewek - z podtytułem Romans na tle stosunków warszawskich - ogłoszono po raz pierwszy w 1888 roku w Warszawie (w bibliografii Estreichera data roczna 1889), w serii Krwawe Dramaty „Biblioteki Romansów i Powieści”, a wznowiono dwukrotnie - już po śmierci autora - w 1911 i 1926 roku, z kolei Sępa - w 1889 roku pierwsze wydanie, a w 1890 drugie (oba nakładem „Biblioteki Romansów i Powieści”). Dla porządku warto odnotować jeszcze jedną, dziś już zapomnianą powieść Nagiela o tytule Kara Boża idzie przez oceany, osnutą na "tle stosunków w Ameryce”, a opublikowaną w Chicago w 1896 roku (tekst jest udostępniany na stronach Harvard University Library ${ }^{6}$ ). Sukces komercyjny Tajemnic Nalewek utorował drogę drugiej powieści. Nazwisko twórcy zrobiło się głośne, publiczność z niecierpliwością oczekiwała na kolejne teksty jego autorstwa ${ }^{7}$. A i sam pisarz postanowił „kuć żelazo póki gorące”. W efekcie egzemplarze dziewiętnastowieczne Sępa zostały zaczytane, co groziło powieści nawet zniknięciem z rynku czytelniczego. Wydawca współczesny tak pisze o okolicznościach, które poprzedziły przygotowanie tekstu do druku:

Prace nad Sępem rozpoczęliśmy tuż po opublikowaniu [...] Tajemnic Nalewek. Okazało się, że zachowały się tylko trzy egzemplarze, jeden w Londynie i dwa

4 M.J. Olszewska, Opowieść o mrocznej stronie miasta - Henryk Nagiel „Tajemnice Nalewek”, w: Zbrodnie, sensacje i katastrofy w prasie polskiej do 1914 roku, red. K. Stępnik, M. Gabryś, Wydawnictwo WSPA, Lublin 2010, s. 139-151 i E. Ihnatowicz, „Tajemnice Nalewek”. Funkcjonalizacja konwencji przewodnika po mieście w polskiej powieści tajemnic końca XIX w. Studium przypadku, w: Człowiek - społeczeństwo - źródła. Studia dedykowane Profesor Jadwidze Hoff, pod red. Sz. Kozaka, D. Opalińskiego, J. Polaczka, Sz. Wieczorka, W. Zawitkowskiej, Wydawnictwo Uniwersytetu Rzeszowskiego, Rzeszów 2014, s. 482-493.

5 E. Ihnatowicz, dz. cyt., s. 483.

6 Zob. H. Nagiel, Kara Boża idzie przez oceany. Powieść na tle stosunków w Ameryce - https://iiif. lib.harvard.edu/manifests/view/drs:6464252\$1i [dostęp: 2.07.2017].

7 O sukcesie czytelniczym Tajemnic Nalewek informują m.in. recenzenci drugiego wydania powieści. W „Tygodniku Ilustrowanym” pisano: „Powieść ta [...] dziś jest może najbardziej aktualna aniżeli wtedy, kiedy ukazała się w druku po raz pierwszy. Wyczerpana doszczętnie należy do utworów wysoce sensacyjnych, pełnych nad wyraz ciekawych epizodów, a odznacza się niezwykłą barwnością tła i doskonałą charakterystyką działających figur" (Ciekawe powieści VIII: „Tajemnice Nalewek” p. H. Nagla, „Tygodnik Ilustrowany” 1911, nr 8, s. 149). 
w Polsce. Kolekcjonerzy przedwojennych książek nawet nie słyszeli o takim tytule. Egzemplarz, do którego udało nam się dotrzeć, nie był kompletny, gdyż brakowało w nim kilku stron. Część innych była urwana ${ }^{8}$.

W 1921 roku powieść Tajemnice Nalewek została sfilmowana. Film (niemy) miał premierę 7 listopada w Warszawie i był debiutem reżyserskim operatora filmowego Franciszka Zyndrama-Muchy. W rolach głównych wystąpili: Leon Trystan - aktor, reżyser, scenarzysta i krytyk filmowy pochodzenia żydowskiego (właśc. Chaim Lejb Wagman, brat Adama Ważyka), Lucyna Grankowska, Stanisław Dobrzyński, Aleksander Zabłocki i Jadwiga Rościszewska.

\section{Inspiracje}

Nagiel był z zawodu prawnikiem, co - zważywszy na charakter jego twórczości - nie jest bez znaczenia. Urodził się i mieszkał w Warszawie. W 1880 roku ukończył Wydział Prawa na rosyjskim Uniwersytecie Warszawskim. Po studiach rozpoczął praktykę adwokacką. W 1885 roku jako adwokat przysięgły otworzył w Warszawie własną kancelarię. Był postacią w stolicy znaną i aktywną, działał w środowisku literacko-dziennikarskim, udzielał się społecznie. Już od lat 70. XIX wieku pisywał do prasy warszawskiej: „Antraktu”, „Kuriera Warszawskiego”, „Wędrowca”. Pod pseudonimem Henio Żaba lub Henryk Ćwiek drukował felietony i wierszyki satyryczne m.in. w „Kolcach” i „Musze”. W latach 1884-1885 współredagował „Dziennik dla Wszystkich”. W 1888 roku pełnił w „Wędrowcu” funkcję kierownika literackiego. Przez czas jakiś przebywał w Paryżu, potem wyjechał do Ameryki. Po powrocie do kraju osiadł we Lwowie. Zmarł na gruźlicę w 1899 roku?

Wydanie powieści Nagiela przypada na czasy rozwoju powieści kryminalnej (czy kryminalno-detektywistycznej), której początki sięgają opowiadania Edgara Allana Poego Zabójstwo przy Rue Morgue opublikowanego w 1841 roku na łamach „Graham’s Magazine”. Fabuła kryminału, w odróżnieniu od fabuł romansowych czy awanturniczo-przygodowych, wiąże się ze zbrodnią i „idzie za porządkiem odkrycia"10 - od morderstwa ku ujawnieniu winowajcy, a zatem odwraca chronologie

8 Informacja ze strony wydawnictwa - http://kryminal.wydawnictwocm.pl/?henryk-nagiel-sep [dostęp: 2.07.2017]. W nocie wydawniczej podobnie, wydawca wspomina jednak o dwóch egzemplarzach powieści - zob. Henryk Nagiel, w: H. Nagiel, Sęp. Romans kryminalny, korekta i red. A. Dybowski, Wydawnictwo CM, Warszawa 2014, s. 411 (nota bez nazwiska autora). Dalej cytaty z tego wydania oznaczam - S, potem numer strony.

9 Dane biograficzne za: E. Sawicka, dz. cyt.

10 R. Caillois, Powieść kryminalna, przeł. J. Błoński, w: tegoż, Odpowiedzialność i styl. Eseje, wybór M. Żurowskiego, sł. wstępne J. Błońskiego, przekł. J. Błoński et al., Państwowy Instytut Wydawniczy, Warszawa 1967, s. 168. 
zdarzeń. Zagadkę rozwiązuje detektyw (amator lub profesjonalista) „używający rozumu”. Poe powołuje do istnienia detektywa C. Augusta Dupina, „chimerycznego samotnika, erudytę i artystę""1" który w Zabójstwie przy Rue Morgue w drodze dedukcji rozwiązuje zagadkę morderstwa w pokoju zamkniętym od wewnątrz, William Wilkie Collins - sierżanta Scotland Yardu Cuffa (Kamień księżycowy), Emil Gaboriau - detektywa Lecoqa (Sprawa Lerouge, przekł. pol. Gdzie winowaj$c a$ ?). Zarówno Poe, jak i jego następcy, tworząc postać detektywa, wzorują się na postaci Eugène’a-François Vidocqa - złodzieja i awanturnika, który przeszedł na stronę prawa, by stać się ojcem nowoczesnej kryminalistyki. W latach 1828-1829 opublikował Pamiętniki (Mémoires de Vidoq, chef de la police de Seret, jusqu'en 1827), w których ze swadą godną powieści łotrzykowskiej przedstawił historię swojego życia, od narodzin do zakończenia pracy w policji. Dzieło, napisane z udziałem publicystów Emila Morice’a i Louisa-François L’Héritiera, stało się bestsellerem. Legenda Vidocqa zaczęła żyć własnym życiem, stając się częścią kultury popularnej. Vidocq dał początek rzeszy postaci literackich, poza wymienionymi m.in. bohaterom powieści Honoriusza Balzaca, Aleksandra Dumasa-ojca, Eugeniusza Sue, Wiktora Hugo. Poza Pamiętnikami Vidocq wydał sześć powieści, których nie napisał samodzielnie (do grona autorów należeli Alfred Lucas i Auguste Vitu) ${ }^{12}$. Collins w Anglii (przyjaciel Karola Dickensa) i Gaboriau we Francji rozpoczynają swoje kariery w latach 60. XIX wieku. W 1887 roku do literatury kryminalnej wkracza Artur Conan Doyle, który powołuje do istnienia postać Sherlocka Holmesa (i jego przyjaciela doktora Watsona) - typ detektywa-indywidualisty i intelektualisty.

Opowiadania kryminalne Poego docierają na ziemie polskie z opóźnieniem i przez lata są znane tylko nielicznym. W 1902 roku we Lwowie ukazuje się Zabójstwo przy Rue Morgue w przekładzie Wojciecha Szukiewicza (pt. Morderstwo na Rue Morgue). Z powieści Vidocqa już w 1845 roku na język polski zostają przetłumaczone Prawdziwe tajemnice Paryża, pozostałe dzieła przez lata są czytane w oryginale lub w przekładach na język angielski lub niemiecki. Kryminały Collinsa i Gaboriau tłumaczone są na język polski od lat 70. XIX wieku, wychodzą w wydaniach osobnych (m.in. w seriach „Biblioteka Najciekawszych Powieści i Romansów” i „Wieczory Powieściowe”) lub ukazują się w prasie w odcinkach (np. w „Tygodniku Romansów i Powieści”, „Dzienniku Warszawskim”. „Gazecie Kieleckiej”, „Dzienniku Polskim”). Kryminały Doyle’a stają się popularne pod koniec XIX wieku. Modzie na powieści kryminalne ulegają zarówno profesjo-

11 M. Płaza, Anioł dziwnych opowieści, w: E.A. Poe, Opowieści miłosne, śmiertelne i tajemne, wybrał, oprac. i posł. opatrzył M. Płaza, przeł. B. Leśmian et al., Vesper, Poznań 2010, s. 784.

12 Zob. M. Michalska, Vidoca François Eugéne, w: Słownik literatury popularnej..., s. 624-625 i T. Cegielski, Detektyw w krainie cudów. Powieść kryminalna i narodziny nowoczesności 1841-1941, Wydawnictwo W.A.B., Warszawa 2015, s. 53-72. 
naliści, jak i debiutanci, by wspomnieć Walerego Przyborowskiego ${ }^{13}$, Kazimierza Chłędowskiego ${ }^{14}$, Adolfa Dygasińskiego ${ }^{15}$ czy Władysława Grajnerta, który potyczkę z recenzentem „Muchy”, Władysławem Buchnerem, wyśmiewającym jego powieść kryminalną Zbrodniarz, przypłacił życiem ${ }^{16}$. Na początku XX wieku na rynku pojawiają się kryminały w wydaniach zeszytowych, tłumaczone z języków obcych lub pisane „hurtowo” przez twórców anonimowych, m.in. seria Tajemnice Szerloka Holmesa Słynnego Ajenta Śledczego. W latach 1909-1910 w Krakowie wychodzi tygodnik kryminalny „Szerlok Holmes”. Upowszechnianie się kryminałów nie wywołuje entuzjazmu wśród krytyków. Już w 1872 roku Eliza Orzeszkowa krytykuje modę na „Févalów, Gaboriau'ów, Skribów, Montépinów”, nazywając ich „talentami sprzedajnymi i leniwymi”, które „usiłują zdobyć sobie jak największą sumę osobistych pożytków w zamian jak najmniejszej dozy położonych trudów" i dlatego oddają się „w niewolnictwo złym namiętnościom i różnorakim ujemnym skłonnościom społeczeństwa, którym schlebiają i służą za bodźce i igraszkę"17.

W latach 80. XIX wieku „powieść kryminalna miała już wyraźne nacechowania gatunkowe, aczkolwiek klasycznej postaci jeszcze nie osiągnęła"18. Wciąż pozostawała pod wpływem romansu, zwłaszcza łotrzykowskiego, powieści grozy i powieści tajemnic, szczególnie Tajemnic Paryża Eugeniusza Sue ${ }^{19}$. Zagadkę

13 Zob. T. Bujnicki, Między "Noca z 3-go na 4-ty Grudnia” a „Liściem akacji” Walerego Przyborowskiego czyli początki polskiej powieści kryminalnej, „Annales Universitatis Paedagogicae Cracoviensis. Studia Historicolitteraria” 2013, t. 13, s. 49-66 i E. Pawlak-Hejno, Powieści kryminalne Walerego Przyborowskiego na łamach „Gazety Kieleckiej”, w: Zbrodnie, sensacje i katastrofy..., S. $119-129$.

14 Zob. R. Stachura-Lupa, Pisać jak Gaboriau. O „Po nitce do kłębka” Kazimierza Chłędowskiego, „Annales Universitatis Paedagogicae Cracoviensis. Studia Historicolitteraria” 2013, t. 13, s. 19-32 i P. Kaczyński, Gaboriau i jego polski naśladowca, Kazimierz Chłędowski, w: Literatura kryminalna. Na tropie źródet, pod red. A. Gemry, Wydawnictwo EMG, Kraków 2015, s. 389-401.

15 Zob. K. Lesicz-Stanisławska, Miejskie tajemnice. Paryż Eugeniusza Sue a Warszawa Adolfa Dygasińskiego, „Zeszyty Naukowe Uniwersytetu Zielonogórskiego. Seria Scripta Humana” 2014, t. 3: Eugeniusz Sue. Życie - twórczość - recepcja, wyd. specjalne, red. D. Kulczycka, A. Narolska, s. 263-276.

16 Zob. J. Siewierski, Powieść kryminalna, Krajowa Agencja Wydawnicza, Warszawa 1979, s. 136-137.

17 E. Orzeszkowa, O przekładzie, w: tejże, Pisma krytycznoliterackie, zebrał i oprac. E. Janowski, Zakład Narodowy im. Ossolińskich, Wrocław-Kraków 1959, s. 56 (pierwodruk: „Tygodnik Wielkopolski" 1872, nr 15).

18 T. Żabski, Proza jarmarczna XIX wieku. Próba systematyki gatunkowej, Wydawnictwo Uniwersytetu Wrocławskiego, Wrocław 1993, s. 198.

19 Sue wprowadził do literatury światowej tematykę wielkomiejską. Miejscem akcji powieści tajemnic jest miasto z jego ciemną, sekretną stroną - rewirami nędzy i występku: knajpami, spelunami, więzieniami, szpitalami, przytułkami, lochami i kanałami. To przestrzeń niepokojąca i niebezpieczna. Bohater Tajemnic Paryża, Rudolf de Gerolstein, jak pisze Umberto Eco, „sędzia i mściciel, dobroczyńca i reformator sytuujący się poza prawem, jest nadczłowiekiem” (U. Eco, Eugeniusz Sue: socjalizm i pocieszenie, w: tegoż, Superman w literaturze masowej. Powieść 
kryminalną wikłano w dzieje miłości, okraszając fabułę wątkami sensacyjnymi w rodzaju porwań, zasadzek, ucieczek, pościgów, napaści i pojedynków, które miały urozmaicać powieść, wzmagać napięcie, a zarazem - jeśli była to powieść w odcinkach - zachęcić czytelników, by sięgnęli po kolejny numer czasopisma. Akcja musiała być szybka, gęsta od zdarzeń, jak pisze Caillois, potrzeba było czasu, by „tajny agent zastąpił pościg śledztwem, szybkość - inteligencją, gwałt - skrytością"20. W 1928 roku przeciw udziałowi w powieści kryminalnej intrygi miłosnej wypowiedział się S. S. Van Dine (Willard Huntington Wright), pisarz i krytyk amerykański, autor Dwudziestu zasad pisania powieści detektywistycznej (Twenty rules for writing detective stores). Przypadek miał ustąpić miejsca porządkowi przyczynowo-skutkowemu, porywy uczuć - surowości dedukcji.

Tadeusz Cegielski, pisząc o kryminale w jego odmianie detektywistycznej, zauważa:

W powieści tego gatunku pojawiają się nie tylko takie elementy fabuły, jak detektyw - profesjonalista lub amator - lecz także przynajmniej dwa inne: tajemnica; niekoniecznie musi nią być zbrodnia!, i łamigłówka, tzw. puzzle. I wreszcie śledztwo, dzięki któremu tajemnica zostanie odkryta, zaś łamigłówka rozwikłana (prawidłowo ułożona) $)^{21}$.

\section{Detektyw}

Postać detektywa jest dla powieści kryminalnej kluczowa. To element, który spaja strukturę powieści i może decydować o jej przynależności do odmiany gatunkowej (np. powieści policyjnej). Co więcej, jeśli jako kreacja literacka typ bohatera okaże się wystarczająco oryginalny, „ponętny” dla czytelnika, staje się „znakiem rozpoznawczym" autora, a nawet - jak pokazuje przykład Holmesa - przez dziesięciolecia „zapładnia” masową wyobraźnię. U początków powieści kryminalnej postać detektywa przypomina łowcę, myśliwego, który do perfekcji opanował sztukę tropienia zwierzyny. Nie jest to jeszcze typ uczonego, analizującego dane w zaciszu biura, biblioteki czy laboratorium. Wiele zawdzięcza przypadkowi, łutowi szczęścia, jest rzutki, energiczny, wykazuje się pomysłowością, stara się przyspieszyć bieg zdarzeń, w starciu z siłami przestępczymi przejmuje inicjatywę. Biega po ulicach miasta, zagląda do nor i spelun, wpada w pułapki i w ręce zbirów, lecz uwalnia się

popularna: między retoryka a ideologiq, przeł. J. Ugniewska, Państwowy Instytut Wydawniczy, Warszawa 1996, s. 68). Wkracza zarówno na salony, jak i schodzi na dno nędzy, by złoczyńcom, bez względu na ich status społeczny czy pochodzenie, wymierzyć sprawiedliwość. Lista naśladowców Sue jest długa - zob. J. Bachórz, Powieść tajemnic..., s. 487-488.

20 R. Caillois, dz. cyt., s. 170.

21 T. Cegielski, dz. cyt., s. 41. 
z więzów i ucieka, zna tajemne korytarze, bramy i przejścia w murach, mówi obcymi językami, strzela z pistoletów i włada szpadą, jest „chemikiem i atletą”, a nade wszystkim aktorem: potrafi się maskować i przebierać ${ }^{22}$. Swoje rozumowanie opiera na obserwacji. Jak pisze Caillois, w toku śledztwa przechodzi „od strzępu sukna do ubrania, od ubrania do krawca, od krawca do klienta"23. Ma upór, spryt i intuicję, doprowadza sprawę przestępstwa do końca, ale, niestety, z powodu typowego dla początków kryminału natłoku wątków sensacyjno-romansowych zdarza się, że na czas jakiś może nawet... zniknąć z kart powieści.

Bohater powieści Nagiela funkcjonuje w świecie powieściowym pod pseudonimem (czy przezwiskiem) Fryga, bo - co podkreślają zarówno jego współpracownicy, jak i sam narrator - jest „ruchliwy jak żywe srebro” ${ }^{24}$. Ma na imię Józef, w Tajemnicach Nalewek jego nazwisko zastępuje litera X., w Sępie - litera Z. (pierwsza kamufluje nazwisko, druga skraca). W parze z ruchliwością idzie jego fizjonomia. Fryga jest mały i szczupły, liczy „dwadzieścia kilka lat”, ma „twarz i wygląd dziecka ulicy, gamena” (TN, 59). Nie rozgląda się, ale „rzuca naokoło wzrokiem badawczym" (TN, 64), czasem z nadmiaru emocji - zamiast siedzieć spokojnie - podskakuje na krześle, a przede wszystkim - odruchowo, mimowolnie pociera nos. W momentach szczególnego natężenia myśli jego twarz ujawnia „setki wrażeń”: zaciekawienie ustępuje miejsca niespodziance, na wargach „wykwita” filuterny uśmiech („widocznie na spotkanie nowej idei”), czoło chmurzy się (S, 234). Fryga pochodzi z rodziny „ludzi względnie zamożnych” (TN, 125). Po śmierci rodziców trafił pod opiekę człowieka obcego, oddany do szkól, mimo zdolności, nie chciał się uczyć, za to „rwał się w świat, ażeby używać” (TN, 125). Roztrwoniwszy resztki majątku, wylądował na bruku. „Sypiał po skwerach, całymi dniami nic nie jadł, chodził w dziurawych butach, a raczej bez butów” (TN, 126). Stoczył się moralnie, zawarł znajomość z włóczęgami i przestępcami, wreszcie za udział w wyprawie złodziejskiej trafił do więzienia. Spotkanie z adwokatem z urzędu, Julkiem, jednym z bohaterów obu powieści, odmieniło życie Frygi. Po uniewinnieniu mężczyzna trafił do straży ogniowej, a następnie został ajentem policyjnym. W Tajemnicach Nalewek pracuje w policji, ma „żonę” Karolcię (z którą żyje bez ślubu) i syna Stacha. W zakończeniu powieści Fryga porzuca posadę ajenta i wraz z rodziną przenosi się na prowincję. W Sępie pojawia się jako osoba prywatna, pracuje jako oficjalista w fabryce cukru. Zostaje wezwany do stolicy przez Julka. Co ciekawe, wkracza do akcji dopiero mniej więcej w połowie powieści.

Przeszłość Frygi w jakiejś mierze uzasadnia jego zdolności śledcze. To inteligencja (cecha wrodzona) połączona z doświadczeniem życiowym i znajomością

22 R. Caillois, dz. cyt., s. 172.

23 Tamże, s. 173.

24 H. Nagiel, Tajemnice Nalewek, korekta i red. A. Lech, Wydawnictwo CM, Warszawa 2013, s. 59. Dalej cytaty z powieści oznaczam - TN, potem numer strony. 
świata przestępczego. Tak jak Vidocq i jedno z jego literackich wcieleń, bohater powieści Gaboriau - policjant Lecoq, Fryga jest człowiekiem, któremu dane było upaść, a potem powrócić na drogę prawa. „Z tego «Frygi» [...] to cały Lecoq” (TN, 128) - mawiają jego współpracownicy. Metody śledcze ajenta policyjnego nie należą do typowych. Fryga jest oryginałem, działa w pojedynkę. Nie przestrzega procedur (np. bez wiedzy przełożonych zabiera z miejsca przestępstwa dowody), rządzi się „cokolwiek przeczuciem i fatalizmem” (TN, 202), czasem zdaje się na przypadek. Jak mówi - ma „swój system pracy”, którego naczelną zasadą jest „poznać stosunki" (TN, 119): zebrać informacje o uczestnikach zdarzenia, zbadać ich przeszłość, upodobania, zwyczaje, relacje rodzinne. „Ty mu pokaż zwykłego złodzieja, a on ci z niego na jutro cały romans przyniesie" (TN, 128). Sukcesy, jak i zaangażowanie, upór i bezkompromisowość zjednują Frydze przychylność przełożonych i budzą podziw wśród współpracowników. „Niech się wszystkie Lecoq’i w kąt schowają" (S, 307) ${ }^{25}$ - wykrzykuje przyjaciel Frygi o przezwisku Wicherek. Naczelnik ma u ajenta dług wdzięczności - podczas jednej z akcji Fryga „dostał uderzenie nożem w ramię, przeznaczone dla swego zwierzchnika" (TN, 248). Śledczy lubi pracę $\mathrm{w}$ terenie. Dowody analizuje w biurze lub w domu, czasem w towarzystwie Karolci, ale to miasto jest jego żywiołem. Podążając śladem przestępców, Fryga odwiedza speluny, włazi do piwnic, wystaje pod bramami kamienic. Prowadzi z przestępcami grę, w której stawką bywa nawet życie. W Tajemnicy Nalewek, uciekając przed pościgiem i gradem kul rewolwerowych, wyskakuje przez okno z wysokości drugiego piętra. Ocalenie zawdzięcza znajomemu stróżowi, Jakubowi, „zresztą mógł się pochlubić, że znał sporo osób w mieście" (TN, 271) - od przedstawicieli śmietanki towarzyskiej po woźniców i Żydów, z którymi rozmawia „po żydowsku". Repertuar trików stosowanych przez Frygę jest imponujący, choć znany już z powieści tajemnic czy przygodowo-awanturniczych. W razie potrzeby śledczy udaje pijanego, przykleja sobie brodę i wąsy, przebiera się za andrusa (zakłada duże blond wąsy, blond hiszpankę i niebieskie okulary, zaczesuje staranie włosy) i za szewca, częstuje podejrzanego cygarem napojonym narkotykami. Wreszcie wśród

25 Przywoływanie postaci sławnych detektywów jest w kryminałach praktyką dość powszechną. Nazwisko Lecoq wymienia np. Doyle w Studium w szkarłacie (Sherlock Holmes nazywa Lecoqa „nędznym partaczem”). Na oryginalność postaci stworzonej przez Gaboriau wskazuje Jürgen Thorwald, dziennikarz, historyk, badacz m.in. dziejów kryminalistyki: „Lecoq był zwolennikiem niezawodnego wnioskowania logicznego - ale był również jeszcze kimś więcej. Dopiero praktyczne oględziny miejsca przestępstwa dostarczały mu materiału, z którego rozwijała się jego śmiała dedukcja. [...] Lecoq po raz pierwszy w literaturze mierzył i oceniał jako detektyw ślady stóp i obuwia, i utrwalał je w odlewach gipsowych. Co więcej: w swoich zadziwiająco wielkich zbiorach śladów gromadził także próbki pyłu, włókna tekstylne, zabrudzenia ziemią i cząstkami roślinnymi, które zdradziły czyny przestępcze i ich sprawców" (J. Thorward, Godzina detektywów. Rozwój i kariera kryminalistyki, przeł. K. i. K. Jaegermanowie, J. Dumański, J. Markiewicz, posłowiem opatrzył J. Markiewicz, wyd. 2, Wydawnictwo Literackie, Kraków 1993, s. 271). 
jego rekwizytów są i nowinki techniczne na miarę wieku pary i elektryczności. Wynająwszy pokój nad podejrzanym, Fryga robi w podłodze otwór, przez który spuszcza „rodzaj telefonu”. Jak wyjaśnia, „jeden z naszych inżynierów w fabryce pracuje nad ulepszeniem telefonu i mikrofonu. Ja mu często pomagałem w tych pracach przez ciekawość... Obecnie to mi się przydało” (S, 400). Zrządzeniem losu podejrzany „lubi rozmawiać sam ze sobą” (S, 400).

Powieść kryminalna XIX wieku ukazuje „świat uładzonej mieszczańskości”26. Zbrodnia jest wykroczeniem przeciw porządkowi społecznemu i moralnemu, zaburza jego rytm i logikę. „Powieść kryminalna przedstawia istotnie walkę czynnika organizacji i czynnika zamętu, których odwieczny antagonizm utrzymuje świat w równowadze"27 - pisze Caillois. Ujawnienie i ukaranie sprawcy przywraca światu porządek, jest triumfem rozumu nad chaosem, instynktem, żądzą. Wśród bohaterów powieści Nagiela przeważają reprezentanci klasy średniej, przeważnie o szlacheckich korzeniach: urzędnicy, finansiści, adwokaci, lekarze, epizodycznie pojawiają się służący, robotnicy, szynkarze czy ludzie z marginesu społecznego - złodzieje, oszuści i prostytutki. W obu powieściach powodem występku jest chciwość. Zbrodniarze nie są zawodowymi przestępcami (choć korzystają z usług osób z półświatka), to żądza posiadania kieruje ich na drogę przestępstwa. Zdemaskowani, osaczeni przez stróżów prawa, w akcie desperacji popełniają samobójstwo (w Tajemnicach Nalewek Natan Lurje wypija truciznę, przeznaczoną dla swojego wspólnika, w Sępie Aleksander Jastrzębski strzela do siebie z pistoletu). Sprawiedliwości staje się zadość, zbiorowość odzyskuje poczucie bezpieczeństwa, powraca wiara w sens i trwałość porządku moralnego. Układ detektyw-morderca odpowiada w powieści Nagiela antynomii dobro-zło. Zbrodniarz kieruje się namiętnością, instynktem, ulega żądzy, działa w sposób spontaniczny, czasem nieprzemyślany, wiedzie życie podwójne, zakłamane, z kolei detektyw - wierzy w siłę intelektu, potrafi poskromić swoje emocje, jeśli trzeba - działać na chłodno. Obaj funkcjonują w społeczeństwie, o ile jednak zbrodniarz udaje przykładnego obywatela (bankiera, urzędnika), o tyle śledczy jest przykładnym obywatelem: ma dom, rodzinę, stoi na stanowisku prawa i praworządności.

\section{Tajemnica}

Tajemnica pojawiała się w tytułach powieści już wcześniej, ale to za sprawą Tajemnic Paryża Sue weszła do słownika terminów literackich jako określenie odmiany powieściowej, uchodzącej za prototyp kryminału - powieści tajemnic. Sue, jak piszą Elżbieta Powązka i Teresa Solecka, zsekularyzował pojęcie tajemnicy, „które dotąd egzystowało w literaturze w znaczeniu raczej mistyczno-religijnym,

26 J. Siewierski, dz. cyt., s. 61.

27 R. Caillois, dz. cyt., s. 205. 
teraz zaś stało się słowem kluczem rozgrywającego się w nowoczesnym mieście kryminału"28. Miejscem akcji powieści tajemnic jest miasto ukazane jako labirynt, dżungla czy mrowisko, po którym kluczą bohaterowie i to zarówno w sensie dosłownym - przemierzając jego ulice, place, zaglądając do sklepów i kawiarni, jak i w sensie metaforycznym - poznając czy rozpoznając swoją kondycję społeczną, przeszłość, dwuznaczność natury ludzkiej. „Co krok czyha tu niebezpieczeństwo. Trzeba mieć wiedzę i instynkt wytrawnego tropiciela, by się po tej dżungli poruszać i wyjść z obieży zwycięsko"29. Przestrzeń miasta jako scenerii zdarzeń ma w powieści tajemnic wymiar horyzontalny i wertykalny. Na sieć ulic i uliczek, rozbiegających się w różnych kierunkach, nakłada się system budowli, z ich klatkami schodowymi, piwnicami i strychami, wymagającymi wspinania się lub schodzenia w dół (po stopniach, po drabinie), plątaniną korytarzy. Miasto ma swoje tajemnice, jest zagadką. Za fasadami, dostępnymi oczom przechodnia, ukrywa się świat groźny, niebezpieczny, egzotyczny, świat występku, który aktywizuje się po zmroku. Wielości i różnorodności miejsc przestawionych w powieści tajemnic, a wchodzących w obręb miasta odpowiada zróżnicowanie społeczne jego mieszkańców - od rentierów, urzędników, lekarzy po robotników i biedotę miejską. Nędza materialna pociąga za sobą nędzę moralną, zepsuciu ulegają jednak i przedstawiciele klas wyższych.

„Wszystko, co znajduje się w pewnej tajemnicy, w pewnym półświetle tym bardziej podnieca naszą fantazję...” (S, 243) - mówi Fryga. „Łowcą tajemnic” bez przesady można nazwać Onufrego Leszcza, bohatera powieści $S e ̨ p$, lubującego się w zbieraniu „na pozór nic nieznaczących przedmiotów” (S, 95) - notatek, dokumentów, starych akt, listów. Filozofia życiowa Onufrego, kamienicznika, syna praczki z Krzywego Koła i byłego komornika, marzącego o milionie, jest prosta - na tajemnicy można zarobić. „Wierz mi - zapewnia Onufry swojego wspólnika Robaka - każda tajemnica, choćby była głupstewkiem, choćby nie miała gruntu zbrodni ani występku, zawsze przedstawia pewną wartość pieniężną!...” (S, 86). W powieściach Nagiela tajemniczość nie łączy się jedynie z wątkiem kryminalnym, zagadką zbrodni i próbą jej rozwiązania, ale wydaje się immanentną cechą świata. Aura tajemniczości spowija Warszawę, będącą miejscem akcji obu powieści (w Sępie epizodycznie pojawia się Paryż) - miasto-wylęgarnię występku ${ }^{30}$, grzechy i grzeszki z przeszłości, starannie ukrywane przed otoczeniem, nie pozwalają bohaterom spać

28 Zob. E. Powązka, T. Solecka, Katabaza dandysa. O „Tajemnicach Paryża”, „Zeszyty Naukowe Uniwersytetu Zielonogórskiego. Seria Scripta Humana" 2014, t. 3: Eugeniusz Sue..., s. 65. Badaczki powołują się na pracę Stephena Knighta The Mysteries of the Cities. Urban Crime Fiction in the Nineteenth Century, North Carolina 2012.

29 J. Bachórz, Powieść tajemnic..., s. 487.

30 Więcej o obrazie Warszawy w powieściach Nagiela na przykładzie Tajemnic Nalewek zob. J. Detko, dz. cyt., M.J. Olszewska, dz. cyt. i E. Ihnatowicz, dz. cyt. 
spokojnie, bo błędy młodości „lubią" mścić się po latach, swoje sekrety mają nawet ludzie zwyczajni, stateczni, powszechnie szanowani, nie wyłączając kobiet - przełożonej pensji (jeszcze jako uboga nauczycielka zaciągnęła dług lichwiarski na rewers ze sfałszowanym podpisem przełożonej, by umożliwić narzeczonemu ucieczkę za granicę) czy Karolci, ukochanej Frygi, niegdyś posądzonej o zabicie dziecka (dziewczyna była guwernantką, zaszła w ciążę z kuzynem pani domu, „gdzieś na poddaszu urodziła dziecko”, jak twierdziła, nieżywe, „które dwa dni potem znaleziono zakopane na podwórzu" - TN, 130). W skrytości, nierzadko pod osłoną nocy i przy akompaniamencie burzy, dochodzi do przedstawionych w powieściach Nagiela aktów przemocy i okrucieństwa: zabójstw, gwałtów, kradzieży, porwań. Przestępcy ukrywają swoją tożsamość, prowadzą podwójne życie, w korespondencji ze swoimi kompanami używają szyfru. W Tajemnicach Nalewek na czele szajki zajmującej się kontrabandą, kradzieżami, szantażami, rozbojami, fałszowaniem plomb i pieczęci stoi Rada Trzech kierowana przez „niego samego”. Organizacja działa na Litwie, w Prusach i w głębi Cesarstwa Rosyjskiego, w powieści jest określana jako „nasi”. Tożsamość „niego samego” pozostaje zagadką do końca. W finale powieści sprawcy kradzieży w banku Ejteles i S-ka zostają ujawnieni, ale szajki nie udaje się rozbić. W Sępie działaniami Robaka i Leszcza kieruje z Paryża mężczyzna, którego tak personalia, jak i przeszłość stają się wiadome dopiero pod koniec powieści. To postać rodem z powieści grozy: lekarz opętany żądzą zemsty, zabójca swojej żony, nieszczęśliwy kochanek o krzaczastych brwiach, zimnych, szarych oczach i głębokiej zmarszczce na czole (S, 272). Sęp mści się na kobiecie, tancerce warszawskiego baletu, która odrzuciła jego miłość - doprowadza do skazania na śmierć jej ukochanego (mężczyzna „dał się wpleść w koło ówczesnych wypadków” (S, 372), jak można się domyślić - uczestniczył w powstaniu styczniowym, po donosie został aresztowany i stracony na oczach swojej ukochanej), a potem prześladuje jej dzieci, bliźniaki rozdzielone w dzieciństwie. Kobieta wariuje, zostaje wywieziona przez Sępa za granicę i zamknięta w jego kryjówce w jednej z paryskich dzielnic nędzy, w kamienicy zwanej Maison Noire („czarny dom”). Sęp jest „osobistością znaną w Paryżu”. Podaje się za Szweda nazwiskiem Eriksen, jest lekarzem i prowadzi badania nad chorobami nerwowymi. „W sferach naukowych i lekarskich świata paryskiego" uchodzi za znakomitość (S, 274). Przezwisko zawdzięcza swojej pozycji materialnej - „ępami” plebs paryski nazywa właścicieli kamienic.

Świat kreowany przez Nagiela jest mroczny, zagmatwany, budzi niepokój. Rozstrzygnięcie zagadki kryminalnej i ukaranie winnych oznacza triumf sprawiedliwości, porządku społecznego, konwenansu, ale nie niweluje poczucia zagrożenia. Śledczy Fryga nie jest cudotwórcą, reformatorem, słowem - Rudolfem z Tajemnic Paryża, który rozwiązuje „w sposób fantastyczny realne dramaty nędznego i tajemnego Paryża"31. Zarówno miasto, jak i jego mieszkańcy nie przestają mieć tajemnic. 
Po śmierci Natana Lurjego szajka z Nalewek kontynuuje swoją działalność, a nawet jeśli zostanie zlikwidowania, jej miejsce zajmie następna. Josek Stiefel, stojący za podwójną kradzieżą w banku Ejtelesa, zabójca Czerwonego Janka, unika kary i ucieka za granicę. Tema nie porzuca profesji kurtyzany, Onufry przepada bez wieści. Zagadką pozostaje los Sępa i jego ofiary, kobiety obłąkanej. Z Paryża do kraju dociera wieść o pożarze w Maison Noire, „w popielisku znaleziono kości ludzkie" (S, 409). Prasa francuska spekuluje, czy był to wypadek czy samobójstwo. „W kilka lat potem jakiś uczony francuski, powróciwszy z podróży dookoła świata, zapewniał, że widział doktora Eriksena w Południowej Ameryce..." (S, 410). Opowieści nie dawano wiary, niczego jednak nie można przesądzić.

\section{Łamigłówka i śledztwo}

Struktura powieści kryminalnej opiera się na relacji: detektyw - ofiara - morderca. Detektyw chce odkryć, kto i dlaczego popełnił zbrodnię, morderca - umknąć pogoni i uniknąć kary. Relacje między ofiarą a zabójcą ustala się w toku śledztwa. Detektywi są z reguły postaciami budzącymi sympatię, choć bywają egocentryczni i ekscentryczni, by wymienić Dupina (który nie znosi dziennego światła), Lecoqa czy Holmesa. Legitymują się inteligencją, sprytem, to geniusze sztuki analitycznej. Krąg przestępców nie jest już tak stypizowany. To przedstawiciele różnych warstw społecznych i zawodów, od arystokratów po kamerdynerów, dla których zabijanie, kradzieże i gwałty nie są profesją. Zbrodnię popełniają w akcie zemsty, ze strachu, z chciwości lub z namiętności. Co ważne, rekrutują się spośród osób z otoczenia ofiary $^{32}$. Akcję powieści kryminalnej rozpoczyna przestępstwo, a ściślej ujawnienie jego efektów - trupa. Rozwiązanie zagadki odwraca chronologię zdarzeń i prowadzi ku przeszłości. W śledztwie ustala się, co poprzedziło zbrodnię, jakie były jej motywy i przebieg, wreszcie - kim jest zabójca (a czasem i ofiara). Jak zauważa Stanko Lasić, „w powieści kryminalnej narracja przekształca się w następstwo wynikające z zagadki, które w płaszczyźnie fabularno-kompozycyjnej realizuje się jako narracja linearno-powrotna"33. Porządek wydarzeń zostaje zastąpiony porządkiem odkrycia ${ }^{34}$. Śledztwo polega na rekonstruowaniu przebiegu zdarzeń na postawie przesłanek, stawianiu i odrzucaniu kolejnych hipotez. Powieść kryminalna „nie opowiada jakiejś historii, ale pracę, która tę historię odkrywa”35. A zatem zbrodnia jest w kryminale i początkiem, i końcem. Daje początek śledztwu, ale i wraz z końcem życia ofiary zamyka jakąś sprawę z przeszłości (chyba że jest

32 Zob. J. Siewierski, dz. cyt., s. 48-51.

33 S. Lasić, Poetyka powieści kryminalnej. Próba analizy strukturalnej, przeł. M. Pertyńska, Państwowy Instytut Wydawniczy, Warszawa 1976, s. 12-13.

34 Zob. R. Caillois, dz. cyt., s. 168.

35 Tamże, s. 169. 
to seria morderstw, w którym ofiarami są osoby przypadkowe, wytypowane przez zabójcę tylko ze względu np. na płeć czy profesję). W efekcie, niezależnie od rozczłonkowania wewnętrznego, podziału na części czy rozdziały, powieść kryminalna ma strukturę trójczłonową. Część pierwsza to ekspozycja ujawniająca zaistnienie przestępstwa, druga jest relacją z dochodzenia, pokazuje detektywa $\mathrm{w}$ trakcie śledztwa, trzecia - dopowiada szczegóły historii, wiążąc w jedną całość to, co dotąd wydawało się być ze sobą niepowiązane (takich wyjaśnień udziela detektyw lub morderca).

Powieści Nagiela zachowują porządek odkrywania, przestępstwo daje początek biegowi zdarzeń. W Tajemnicach Nalewek z kasy banku Ejteles i S-ka znika spora suma pieniędzy, niedługo potem w mieszkaniu zostają odnalezione zwłoki kasjera Mojżesza Halbersona, który w dniu przestępstwa nie stawił się do pracy. W Sępie ginie ksiądz Andrzej Suski, proboszcz w Rogowie. W obu powieściach o popełnienie przestępstwa zostają oskarżone niewinne osoby: w Tajemnicach Nalewek dowody zdają się wskazywać na Janka Strzeleckiego, głównego magazyniera w firmie Ejteles i S-ka, w Sępie o zbrodnię zostaje posądzony podopieczny księdza, Stefan Polner. Obrońcą obu młodzieńców jest adwokat Julek, przyjaciel Janka, niegdysiejszy dobroczyńca Frygi. W Tajemnicach Nalewek detektyw pojawia się już na początku śledztwa jako pracownik policji. Wiedziony intuicją, jak i znajomością duszy ludzkiej, nie wierzy w winę oskarżonego, dlatego współpracuje z jego adwokatem. Podczas oględzin mieszkania Halbersona odnajduje strzępy listu i fotografie dwóch kobiet. Dzięki pomocy Karolci („detektywi w spódnicy” pojawiają się np. w powieściach Collinsa) odczytuje treść kawałka korespondencji. Dalsze śledztwo prowadzi Frygę do magazynów Apenszlaka, w których szajka przemytników przechowuje towar i wytwarza fałszywe pieczęcie. Detektyw zostaje przyłapany przez złoczyńców, ucieka, ale po upadku z dużej wysokości na czas jakiś zostaje wyeliminowany z gry. Szczegóły swojego śledztwa zdradza naczelnikowi. W Sępie działania Frygi schodzą na plan dalszy. Postacią pierwszoplanową jest Onufry, usiłujący - na żądanie Sępa - odnaleźć i zniszczyć parę bliźniąt - Jadwigę i Stefana Polnerów, dzieci baletnicy. Po skazaniu Stefana, do czego przyczynił się donos i fałszywe zeznania ludzi podstawionych przez Onufrego, stawką w grze jest życie i dobre imię Jadzi. W Sępie Fryga popisuje się umiejętnościami analitycznymi, ale nie jest już tak aktywny jak w Tajemnicach Nalewek. Analizuje dowody, dokonuje oględzin miejsca zbrodni (z rąk Robaka ginie szewc, który stanął w obronie Jadzi), obserwuje i podsłuchuje podejrzanych, wydaje się jednak działać na chłodno, metodycznie, nie biega, a rozważa. W zakończeniu obu powieści wyjaśnienia Frygi spinają okoliczności zabójstwa w jedną całość.

W powieściach Nagiela wątek kryminalny przeplata się z sensacyjno-romansowym, co momentami zaburza przebieg śledztwa. Wprowadzenie scen porwań, pogoni i gwałtów, które czynią akcję obu powieści szybką i efektowną, dokonuje się kosztem gry intelektualnej, jaką w powieści kryminalnej ścigany prowadzi ze 
ścigającym. Efektowność śledztwa ustępuje pola efektowności intrygi. Porwane lub porzucone dzieci, uwiedzione dziewczęta, mężczyźni o podwójnej tożsamości, kobiety sprzedajne, gang przemytników i banda złodziei kolejowych, a w tle namiętność, która nie cofnie się przed niczym - katalog pomysłów fabularnych wykorzystanych przez Nagiela w Tajemnicach Nalewek i Sępie zdaje się nie mieć końca. Fryga finalizuje obie sprawy, ale czy ich rozwiązanie „zadowala inteligencję"36? Czyż wobec postępków np. Sępa historie Lurjego i Jastrzębskiego nie wydają się banalne? Ot, pospolici przestępcy...

Powieści Nagiela tkwią jeszcze w żywiole tradycji powieści tajemnic, awanturniczo-przygodowej, nawet grozy, a zarazem posiadają elementy, które z czasem staną się filarami konwencji powieści kryminalnej: postać detektywa prowadzącego śledztwo w oparciu o wnioskowanie; strukturę opowiadania idącego za porządkiem odkrycia, a podzielonego na etapy: ekspozycja, śledztwo i zdemaskowanie sprawcy; umieszczenie przesłanek wskazujących na przebieg przestępstwa w tekście, tak by czytelnik nie tylko towarzyszył detektywowi, ale i miał możliwość dociekania prawdy na własną rękę; usytuowanie mordercy w kręgu osób związanych z ofiarą. Porównanie Frygi do Lecoqa nie jest przypadkowe - jak się wydaje, to Gaboriau, którego powieści kryminalne uchodzą za ogniwo łączące Poego z Doyle'em ${ }^{37}$, patronuje powieściom Nagiela, co - rzecz jasna - nie umniejsza, wskazywanego już przez badaczy, zwłaszcza w odniesieniu do Tajemnicy Nalewek, wpływu Sue.

\section{Bibliografia}

Bachórz Józef, Polska powieść tajemnic w pierwszym ćwierćwieczu jej istnienia, w: Formy literatury popularnej, pod red. Aleksandry Okopień-Sławińskiej, Zakład Narodowy im. Ossolińskich, Wydawnictwo PAN, Wrocław-Warszawa 1973, s. 115-135.

Bachórz Józef, Powieść tajemnic, w: Słownik literatury popularnej, pod red. T. Żabskiego, Wydawnictwo Uniwersytetu Wrocławskiego, Wrocław 2006, s. 485-488. Bujnicki Tadeusz, Między „Noca z 3-go na 4-ty Grudnia” a „Liściem akacji” Walerego Przyborowskiego czyli początki polskiej powieści kryminalnej, „Annales Universitatis Paedagogicae Cracoviensis. Studia Historicolitteraria” 2013, t. 13, s. 49-66.

Caillois Roger, Odpowiedzialność i styl. Eseje, wybór Macieja Żurowskiego, sł. wstępne Jana Błońskiego, przekł. Jan Błoński et al., Państwowy Instytut Wydawniczy, Warszawa 1967.

36 Tamże.

37 Zob. T. Cegielski, dz. cyt., s. 194. 
Cegielski Tadeusz, Detektyw w krainie cudów. Powieść kryminalna i narodziny nowoczesności 1841-1941, Wydawnictwo W.A.B, Warszawa 2015.

Detko Jan, Warszawa naturalistów, Państwowy Instytut Wydawniczy, Warszawa 1980. Eco Umberto, Superman w literaturze masowej. Powieść popularna: między retoryka a ideologia, przeł. Joanna Ugniewska, Państwowy Instytut Wydawniczy, Warszawa 1996.

Ihnatowicz Ewa, „Tajemnice Nalewek”. Funkcjonalizacja konwencji przewodnika po mieście w polskiej powieści tajemnic końca XIX w. Studium przypadku, w: Człowiek - społeczeństwo - źródła. Studia dedykowane Profesor Jadwidze Hoff, pod red. Szczepana Kozaka, Dariusza Opalińskiego, Janusza Polaczka, Szymona Wieczorka, Wioletty Zawitkowskiej, Wydawnictwo Uniwersytetu Rzeszowskiego, Rzeszów 2014, s. 482-493.

Kaczyński Paweł, Gaboriau i jego polski naśladowca, Kazimierz Chłędowski, w: Literatura kryminalna. Na tropie źródeł, pod red. A. Gemry, Wydawnictwo EMG, Kraków 2015, s. 389-401.

Lasić Stanko, Poetyka powieści kryminalnej. Próba analizy strukturalnej, przeł. Magdalena Petryńska, Państwowy Instytut Wydawniczy, Warszawa 1976.

Lesicz-Stanisławska Katarzyna, Miejskie tajemnice. Paryż Eugeniusza Sue a Warszawa Adolfa Dygasińskiego, „Zeszyty Naukowe Uniwersytetu Zielonogórskiego. Seria Scripta Humana” 2014, t. 3: Eugeniusz Sue. Życie - twórczość - recepcja, wyd. specjalne, red. Dorota Kulczycka, Aneta Narolska, s. 263-276.

Nagiel Henryk, Sęp. Romans kryminalny, korekta i red. Arkadiusz Dybowski, Wydawnictwo CM, Warszawa 2014.

Nagiel Henryk, Tajemnice Nalewek, korekta i red. A. Lech, Wydawnictwo CM, Warszawa 2013.

Olszewska Maria Jolanta, Opowieść o mrocznej stronie miasta - Henryk Nagiel „Tajemnice Nalewek", w: Zbrodnie, sensacje i katastrofy w prasie polskiej do 1914 roku, red. Krzysztof Stępnik, Monika Gabryś, Wydawnictwo WSPA, Lublin 2010, s. 139-151.

Paczkowski Andrzej, Prasa polonijna w latach 1870-1939. Zarys problematyki, Biblioteka Narodowa, Warszawa 1977.

Płaza Maciej, Anioł dziwnych opowieści, w: Edgar Allan Poe, Opowieści miłosne, śmiertelne i tajemne, wybrał, oprac. i posł. opatrzył Maciej Płaza, przeł. Bolesław Leśmian et al., Vesper, Poznań 2010.

Powązka Elżbieta, Solecka Teresa, Katabaza dandysa. O „Tajemnicach Paryża”, „Zeszyty Naukowe Uniwersytetu Zielonogórskiego. Seria Scripta Humana" 2014, t. 3: Eugeniusz Sue. Życie - twórczość - recepcja, wyd. specjalne, red. Dorota Kulczycka, Aneta Narolska, s. 59-96.

Sawicka Elżbieta, Henryk Nagiel i tajemnice Nalewek, w: Warszawa pozytywistów, pod red. Janiny Kulczyckiej-Saloni i Ewy Ihnatowicz, Wydawnictwo Instytutu Badań Literackich PAN, Warszawa 1992. 
Siewierski Jerzy, Powieść kryminalna, Krajowa Agencja Wydawnicza, Warszawa 1979.

Stachura-Lupa Renata, Pisać jak Gaboriau. O „Po nitce do kłębka” Kazimierza Chłędowskiego, „Annales Universitatis Paedagogicae Cracoviensis. Studia Historicolitteraria" 2013, t. 13, s. 19-32.

Thorward Jürgen, Godzina detektywów. Rozwój i kariera kryminalistyki, przeł. Krystyna i Kazimierz Jaegermanowie, Jerzy Dumański, Jan Markiewicz, posłowiem opatrzył Jan Markiewicz, wyd. 2, Wydawnictwo Literackie, Kraków 1993.

Żabski Tadeusz, Proza jarmarczna XIX wieku. Próba systematyki gatunkowej, Wydawnictwo Uniwersytetu Wrocławskiego, Wrocław 1993.

Renata Stachura-Lupa

\section{Detektyw Fryga na tropie. Henryk Nagiel Tajemnica Nalewek i Sęp}

Streszczenie

Powieści Nagla na ogół nie zwracały uwagi badaczy, z wyjątkiem pewnych odniesień w pracach poświęconych rozwijaniu powieści kryminalnych w Polsce, obrazu Warszawy w literaturze polskiej XIX wieku czy historii polskiej prasy emigracyjnej. Pisząc kryminały - Tajemnice Nalewek i Sępa - autor podążał za przykładem powieści obcojęzycznych, przede wszystkim angielskich i francuskich. Główny bohater jego kryminałów, detektyw Fryga, nie jest jeszcze typem naukowca, który prowadzi śledztwo w zaciszu swojego biura, biblioteki czy laboratorium. Przypomina Vidocqa i jednego z jego literackich odpowiedników, protagonistę powieści Gaboriau - policjanta Lecoqa. Podczas śledztwa Fryga wiele zawdzięcza przypadkowi i szczęściu, jest aktywny, energiczny i twórczy, starając się zaś przyspieszyć tempo wydarzeń, przejmuje inicjatywę $\mathrm{w}$ walce $\mathrm{z}$ przestępczością. W powieści Nagla tajemnica wiąże się nie tylko z motywem zbrodni, sekretem skrytym za przestępstwem i próbą rozwiązania, ale wydaje się nieodłącznym elementem rzeczywistości. Świat stworzony przez Nagla jest mroczny, niejednoznaczny i wywołuje niepokój. Rozwiązanie zagadki kryminalnej i ukaranie winnych oznacza zwycięstwo sprawiedliwości, porządku społecznego i konwencji, ale nie eliminuje poczucia zagrożenia.

Słowa kluczowe: XIX wiek, powieść kryminalna, powieść tajemnic, Henryk Nagiel 


\title{
Detective Fryga on track. Henryk Nagiel's Tajemnica Nalewek (Mystery of Nalewki) and Sęp (Vulture)
}

\author{
Summary
}

Nagiel's novels have not attracted researchers' attention, except for some references to works devoted to the development of mystery novels in Poland, the image of Warsaw in Polish literature of the $19^{\text {th }}$ century, or the history of Polish immigrant society press. When writing his crime novels - Tajemnica Nalewek and Sęp - the author followed the example of foreign novels, mainly English and French ones. The main character of his crime novels, detective Fryga, is not the scientist type who investigates data in his quiet office, library or laboratory. He resembles Vidocq and one of his literary counterparts, the character of Gaboriau's novel - policeman Lecoq. In his investigation, he owes a lot to coincidence and luck; he is active, energetic and creative, trying to speed up events, he takes the initiative in the fight against crime. In Nagiel's novels, mystery not only is connected with the motif of crime, the secret behind the crime and an attempt to solve it, but also seems to be an inherent element of the world. The world created by Nagiel is dark, complex and anxiety-provoking. Solving the crime stories and punishing culprits mean the triumph of justice, social order and convention, but they do not eliminate the sense of threat.

Keywords: $19^{\text {th }}$ century, crime novel, mystery novel, Henryk Nagiel

Renata Stachura-Lupa - dr hab. prof. UP; pracownik Katedry Literatury Polskiej XIX wieku oraz Katedry Literatury Współczesnej i Krytyki Literackiej w Instytucie Filologii Polskiej Uniwersytetu Pedagogicznego im. KEN w Krakowie. Badaczka pozytywizmu, autorka monografii Adam Bełcikowski - pisarz i historyk literatury (Kraków 2005) i Poglądy ideowo-estetyczne Stanisława Tarnowskiego (Kraków 2016), a także artykułów w czasopismach naukowych i pracach zbiorowych, redaktorka monografii wieloautorskich, współorganizatorka krajowych i międzynarodowych konferencji naukowych. Uczestniczy w ogólnopolskich projektach badawczych. Jej zainteresowania naukowe koncentrują się na związkach literatury z filozofią, religią i polityką, krytyce literackiej 2. poł. XIX w. i życiu artystycznym Krakowa w dobie autonomii galicyjskiej. 